Научная статья

УДК 373.24

DOI: $10.18101 / 2307-3330-2021-3-64-69$

\title{
ДЕТСКИЙ САД КАК ПЛОЩАДКА РАЗВИТИЯ КОМПЕТЕНЦИИ ВОСПИТАТЕЛЯ ПО СТАНДАРТУ WORLDSKILS
}

\author{
(C) Желибо Марина Анатольевна \\ аналитик по дошкольному образованию, \\ Центр мониторинга и развития образования комитета по образованию \\ Россия, 670000, г. Улан-Удэ ул. Ленина, 28 \\ zhelibo_marina@mail.ru
}

\begin{abstract}
Аннотация. В статье раскрывается опыт взаимодействия ДОО и Педагогического колледжа в целях сотрудничества в организации работы по подготовке специалистов, направленной на развитие социального партнерства обеспечивающего возможность готовить самостоятельных, конкурентоспособных, компетентных специалистов, а также вопрос касается повышения и развития уровня профессиональной компетентности педагогов ДОО. Представлены результаты реализации проекта по созданию и внедрению модели профессионального развития педагога дошкольного образования посредством сетевого взаимодействия с точки зрения деятельностного подхода. Личность педагога является мощным инструментом в процессе воспитания подрастающего поколения. Чем совершеннее этот инструмент, тем успешнее профессиональный результат. Оптимальное развитие личности педагога происходит в процессе успешного овладения профессиональной деятельностью, значимой для него. В настоящее время существует большое разнообразие курсов повышения квалификации для педагогов, однако эти курсы не всегда соответствуют ожидаемым результатам, затратны и происходят в отрыве от производства. Образовательная среда детского сада обеспечивает перевод полученных знаний в область практических действий, интеграцию личностного и профессионального компонента, что способствует формированию целостности профессиональной позиции как системообразующего фактора процесса повышения квалификации. В статье представлен принципиально новый механизм методического сопровождения профессионального развития педагога посредством качественного сетевого взаимодействия воспитателей и специалистов дошкольной образовательной организации через создание специальных условий для развития творческого потенциала педагогов.
\end{abstract}

Ключевые слова: softskills педагогов, профессиональная устойчивость педагогов, эмоциональный интеллект, самосовершенствование, коммуникативные навыки.

\section{Для цитирования}

Желибо М. А. Детский сад как площадка развития компетенции воспитателя по стандарту Worldskils // Вестник Бурятского государственного университета. Образование. Личность. Общество. 2021. № 3. С. 64-69.

Дошкольное образовательное учреждение в современных условиях нуждается в высококвалифицированных, творчески мыслящих специалистах, владеющих инновационными педагогическими технологиями, в педагогах, способных гибко адаптироваться к новой среде, активно ее преобразовывать, создавать новые воз- 
M. А. Желибо. Детский сад как площадка развития компетенции воспитателя по стандарту Worldskils

можности. Главным потенциалом в процессе формирования профессиональных компетенций студентов колледжа является тесное партнерское сотрудничество студентов с педагогами-практиками, что дает возможность на практике приобщаться к будущей профессии. Наше дошкольное учреждение на протяжении нескольких лет активно сотрудничает с Бурятским республиканским педагогическим колледжем как площадка для оттачивания мастерства студентов. Наше партнерство организовано по нескольким направлениям:

- ДОО как база для прохождения производственной педагогической практики (распределение студентов на возрастные группы, закрепление за каждым студентом педагога-наставника).

- Подготовка студентов к чемпионату WorldSkils по компетенции дошкольное воспитание. При подготовке конкурсных заданий (режимные моменты, показ занятии, игра) Примерные конкурсные задания студенты отрабатывают на нашей базе, также воспитанники нашего детского сада участвуют в качестве волонтеров в период прохождения чемпионата.

- Участие педагогов ДОО в новом направлении чемпионата WorldSkils «Навыки мудрых» для профессионалов старше 50.

Компетентность специалиста формируется только в практической деятельности, поэтому объем практики в ДОУ должен быть максимально большой, определенный ФГОС СПО. Мы определили основные параметры в профессиональной подготовке воспитателя детского сада, которые студенты должны освоить в ходе ознакомления с опытом педагогов на практике:

- умение вести воспитательно-образовательную работу с детьми дошкольного возраста в соответствии с современными требованиями;

- овладение навыками исследовательской культуры (представленных в ФГОС ДО в виде целевых ориентиров дошкольного образования);

- освоение учебно-методических и социально-педагогических умений.

В работе со студентами мы используем различные формы представления актуального педагогического опыта на разных этапах профессиональной подготовки.

- Для первокурсников - это демонстрация принципов организации режимных моментов в группе и объяснение сути происходящего. Также студенты активно включаются в работу в качестве помощника воспитателя, и им предоставляется возможность с небольшой подгруппой детей на практике закрепить все виды деятельности, что дает воспитатель детям всей группы.

- Студенты поэтапно осваивают кроме содержательной стороны педагогического процесса (чему учить?) его технологию (как учить?) и технику (как воздействовать на воспитанника?). Наблюдая работу воспитателя-мастера в практической деятельности, студенты заимствуют педагогическую технику.

- Студенты старших курсов становятся участниками мастер-классов, дискуссионных клубов, членами творческих групп, разрабатывающих один из актуальных вопросов совершенствования работы с детьми.

На протяжении трех лет мы являемся экспертами чемпионата WorldSkills международного некоммерческого движения, целью которого является повыше- 
ние престижа рабочих профессий и развитие профессионального образования путем выявления лучших практик и профессиональных стандартов во всем мире. Участие в качестве эксперта способствует развитию и совершенствованию организации методической работы с педагогами в целях повышения профессиональной компетенции воспитателей нашего сада.

В связи с введением профессионального стандарта «Педагог» и задачами по реализации ФГОС ДО в дошкольном образовании возрастают требования к уровню профессиональной подготовки педагогов. Чтобы в полной мере выполнять требования, которые ФГОС ДО и профессиональный стандарт педагога выдвигают к воспитателям детского сада, педагогу необходимо быть ответственным, умеющим публично выступать, креативным и уметь отстаивать свою точку зрения, обладать гибкими навыками - softskills навыками.

В нашем педколлективе родилась идея: создать условия для развития softskills компетенций у воспитателей. Так обозначился проект «Навыки роста», цель которого - развивать базовые коммуникативные навыки, навыки эффективного мышления, навыки управления собой, способствовать личностному росту педагога, что качественно повлияет на развитие профессионального потенциала педагогов в области социально-психологических навыков.

Начали мы с того, что в сентябре 2019 г. был проведен мониторинг «Softskills современного педагога ДОУ». Результаты исследования показали, что только отдельные навыки развиты у педагогов до уровня опыта и отсутствуют навыки, характеризующие уровень мастерства. У большинства педагогов, к примеру, один из навыков был сформирован на начальном уровне.

Нами был составлен план работы по совершенствованию softskills навыков с нашими педагогами.

В научно-методической литературе выделены четыре типа softskills-навыков:

1) социальные компетенции: эмоциональный интеллект и гибкость, принятие критики, ораторские способности - коммуникабельность;

2) лидерские компетенции: формировать команду, умение брать на себя ответственность, умение принимать решения, разрешать конфликты;

3) интеллектуальные компетенции: самообучаемость, умение вычленять и решать проблему, креативность;

4) волевые компетенции: умение добиваться результат, тайм-менеджмент, стрессоустойчивость, готовность к монотонной, рутинной работе.

Творческой группой выделены следующие навыки:

- Навык эффективного общения (как в диалоге, так и в письме). Учит нас слушать и слышать, убеждать и аргументировать оппоненту, выстраивать доброжелательные отношения с родителями, вести «переговоры», выступать с презентацией, публично выступать при транслировании своего педагогического опыты.

- Умение работать в команде. Учит проявлять эмпатию, нацеливает на результат, учит слышать коллег и влияет на имидж образовательного учреждения. 
M. А. Желибо. Детский сад как площадка развития компетенции воспитателя по стандарту Worldskils

- Понимание влияния технологий на работу. Развивает способность гибко реагировать на выдвигаемые требования, например, на цифровизацию образовательного процесса.

- Способность мыслить критически и не бояться высказывать свое мнение.

Таким образом, опираясь на стандарты WorldSkils, нами была разработана «система методов развития навыков». И после того, как стали внедрять систему методов в работу, мы столкнулись с проблемами, которые обозначились при реализации данного проекта.

- Участие в методических объединениях, где можно получить возможность перенимать педагогический опыт коллег из других ДОО, на практике такой возможности нет, методических объединений за экспериментальный год не было ни одного.

- $\quad$ Не все педагоги хотят и желают заниматься саморазвитием.

- Возникли проблемы - новые методы увидели, услышали, посмотрели, но внедрять у себя не торопимся в силу разных причин.

- У нас возникают трудности с тем, что участие во всех разработках, peaлизациях принимают одни и те же педагоги, и есть педагоги, которым это удобно. Удобно не брать на себя ответственность, инициативу, что со временем приводит к тому, что это становится нормой, теряются новизна и интерес к работе, пропадает желание запускать и принимать участие в больших проектах.

- Не все педагоги нашего детского сада демонстрируют уверенные навыки подготовки к публичному выступлению, вовлечения аудитории и удержания внимания участников, умеют создавать и проводить динамичные, эффективные и конструктивные выступления при проведении образовательной деятельности, на педагогических советах, родительских собраниях.

Высокий уровень «мягких», социальных навыков является основой и гарантом профессиональной успешности педагога. Нам есть к чему стремиться, ведь не все педагоги достигли уровня мастерства. Поэтому мы видим перспективу в дальнейшей работе по развитию softskills навыков. По итогам проведенной рефлексии большая часть педагогов пришла к выводу, что от планомерного развития softskills навыков не только человек становится другим - прогрессивным, творческим, ответственным, но и коллектив в целом начинает выглядеть поиному - развитым, передовым, зрелым.

В заключение отметим, что сотрудничество, организованное в сетевом взаимодействии детского сада и колледжа в вопросах профессиональной подготовки будущих педагогов, позволяет готовить компетентных, самостоятельных, творческих специалистов, конкурентоспособных, а также повышает и развивает уровень профессиональной компетентности педагогов ДОУ.

\section{Литература}

1. Современные детерминанты развития soft skills / С. Н. Бацунов, И. И. Дереча, И. М. Кунгурова, Е. В. Слизкова // Концепт. 2018 . № 4. URL: 
https://cyberleninka.ru/article/n/sovremennye-determinanty-razvitiya-soft skills (дата обращения: 05.06.2019). Текст: электронный.

2. Богдан Е. С. Развитие у студентов инженерных направлений soft skills как важный фактор их конкурентоспособности // Актуальные проблемы гуманитарных и естественных наук. 2017. № 2-4. С. 17-20. Текст: непосредственный.

3. Духновский В. В., Рахманский В. Л., Речкалова О. Л. Выраженность психологической устойчивости и ситуационных реакций у субъектов образовательного процесса, переживающих кризис // Вестник Южно-Уральского государственного университета. Сер.: Психология. Челябинск. 2015. Т. 8, № 3. С. 36-43. Текст: непосредственный.

4. Ивонина А. И., Чуланова О. Л., Давлетшина Ю. М. Современные направления теоретических и методических разработок в области управления: pоль softskills и hard skills в профессиональном и карьерном развитии сотрудников // Науковедение. 2017. Т. 9, № 1. C. 1-18. URL: http://naukovedenie.ru/PDF/90EVN117.pdf (дата обращения: 05.06.2019). Текст: электронный.

5. Лазарев М. А., Стукалов О. В., Темиров Т.В. Профессиональная устойчивость будущих педагогов: потенциал в процессе подготовки и критерии // Наука и школа. 2018. № 2. С. 62-68. Текст: непосредственный.

6. Остроумова О. Ф. Формирование профессиональной устойчивости у студентов факультета иностранных языков // Образование в зеркале философии: материалы межвузовской научной конференции. Казань: Менеджмент, 1998. С. 111-114. Текст: непосредственный.

7. Перевалова А. А Профессиональная стабильность будущего педагога. Исследование профессиональной устойчивости педагога // Вестник Кемеровского государственного университета. 2014. № 4-1 (60). С. 81-86. Текст: непосредственный.

8. Раицкая Л. К., Тихонова Е. В. Soft skills в представлении преподавателей и студентов российских университетов в контексте мирового опыта // Вестник Российского университета дружбы народов. Сер. Психология и педагогика. 2018. Т. 15, № 3. С. 350-363. Текст: непосредственный.

9. Савченков А. В. Экстремальная педагогика как фактор формирования эмоциональной устойчивости педагога // Вестник Новосибирского государственного педагогического университета. 2018. № 5. C. 22-40. DOI 10.15293/2226-3365.1805.02. Текст: непосредственный.

10. Сальная Л. К. Soft skills в компетентностной модели выпускника вуза // Наука. Образование. Культура. Вклад молодых исследователей: сборник статей III Международной научной конференции преподавателей, молодых ученых, аспирантов и студентов вузов / Южно-Российский государственный политехнический университет (НПИ) имени М. И. Платова; под редакцией Л. Н. Соколовой. Москва, 2016. С. 331-334. Текст: непосредственный.

Статья поступила в редакцию 18.11.2021; одобрена после рецензирования 22.11.2021; принята к публикации 07.12.2021.

\section{KINDERGARTEN AS A TEACHER COMPETENCE DEVELOPMENT PLATFORM ACCORDING TO THE WORLDSKILLS STANDARD}

\section{Marina A. Zhelibo}

Preschool education analyst

Center for Monitoring and Development of Education of Education Committee 
28 Lenin St., Ulan-Ude, 670000 Russia

zhelibo_marina@mail.ru

The article reveals the experience of interaction between the Preschool Educational Institution and Pedagogical College in order to cooperate in the organization of work on training specialists aimed at the development of social partnership, which will make it possible to train independent, competitive, competent specialists. And also about improving and developing the level of professional competence of preschool teachers. The results of the project on the creation and implementation of a model of professional development of a teacher of preschool education through networking from the point of view of the activity approach are presented. The personality of a teacher is a powerful tool in the process of educating the younger generation. The more perfect this tool is, the more successful the professional result is. The optimal development of the teacher's personality takes place in the process of successfully mastering the professional activity that is significant for him. Currently, there is a wide variety of advanced training courses for teachers, but these courses do not always meet the expected results, are costly and occur in isolation from work. The educational environment of the kindergarten provides the translation of the acquired knowledge into the field of practical actions, the integration of personal and professional components, which contributes to the formation of the integrity of the professional position as a system-forming factor in the process of professional development however, these courses do not always meet the expected results, are costly and occur in isolation from production. The educational environment of the kindergarten provides the translation of the acquired knowledge into the field of practical actions, the integration of personal and professional components, which contributes to the formation of the integrity of the professional position as a systemforming factor of the professional development process. The article presents a fundamentally new mechanism of methodological support for the professional development of a teacher through high-quality network interaction of educators and specialists of a preschool educational institution, through the creation of special conditions in the organization for the development of the creative potential of teachers.

Keywords: «soft skills» of teachers, professional stability of teachers, emotional intelligence, self-improvement, communication skills.

The article was submitted 18.11.2021; approved after reviewing 22.11.2021; accepted for publication 07.12.2021. 